\title{
Erratum: High-throughput quantitation of inorganic nanoparticle biodistribution at the single-cell level using mass cytometry
}

Yu-Sang Sabrina Yang, Prabhani U. Atukorale, Kelly D. Moynihan, Ahmet Bekdemir, Kavya Rakhra, Li Tang, Francesco Stellacci \& Darrell J. Irvine

Nature Communications 8:14069 doi: 10.1038/ncomms14069 (2017); Published 17 Jan 2017; Updated 14 Aug 2017

In Fig. $4 \mathrm{~d}$ of this Article, the schematic was incorrectly illustrated with one SIINFEKL peptide detached from a MUS/OT nanoparticle surface. The correct version of Fig. 4 appears below as Fig. 1.

\footnotetext{
(c) (i) This work is licensed under a Creative Commons Attribution 4.0 International License. The images or other third party material in this article are included in the article's Creative Commons license, unless indicated otherwise in the credit line; if the material is not included under the Creative Commons license, users will need to obtain permission from the license holder to reproduce the material. To view a copy of this license, visit http://creativecommons.org/licenses/by/4.0/
}

(C) The Author(s) 2017 
a
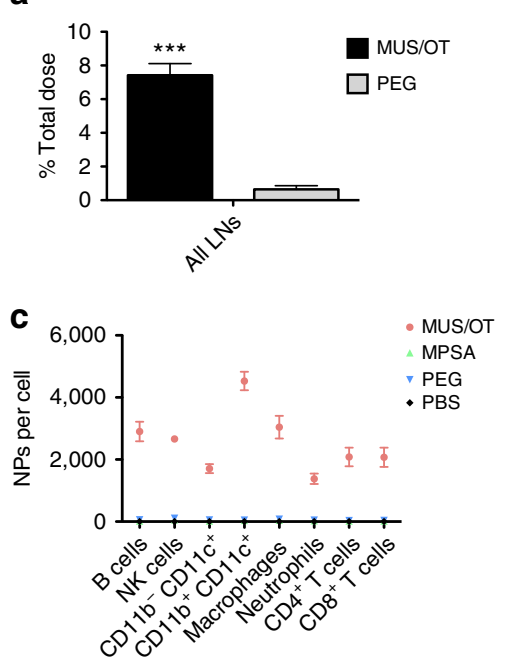

b
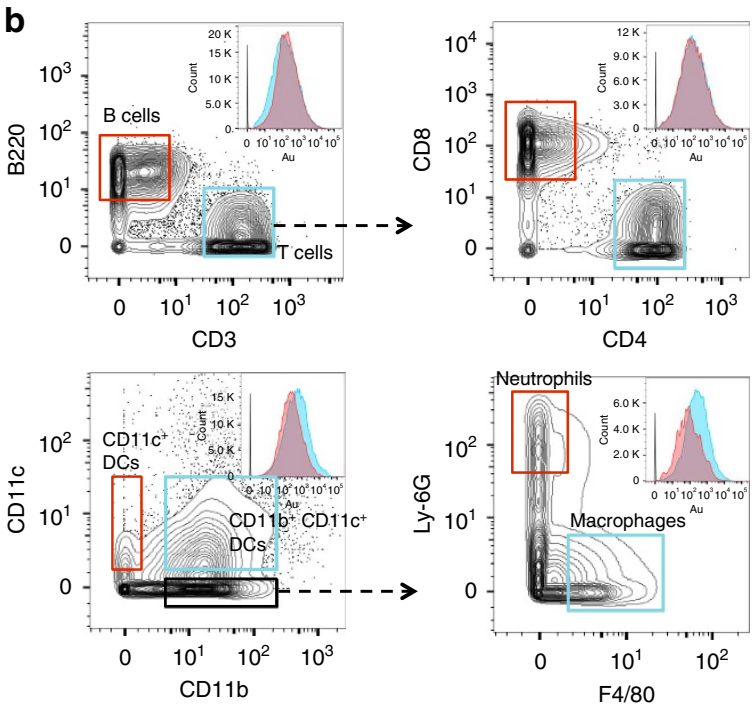

d
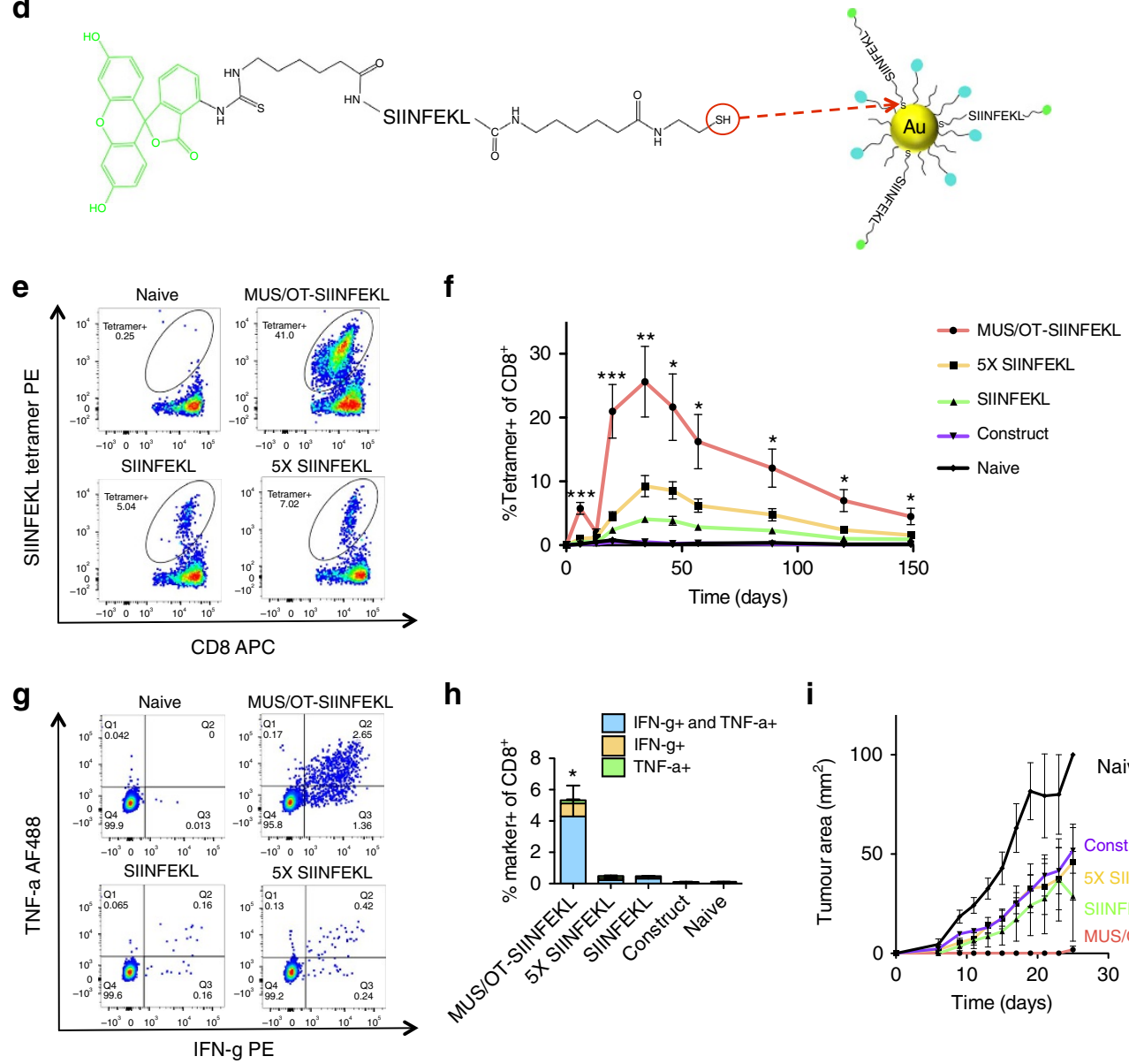

h
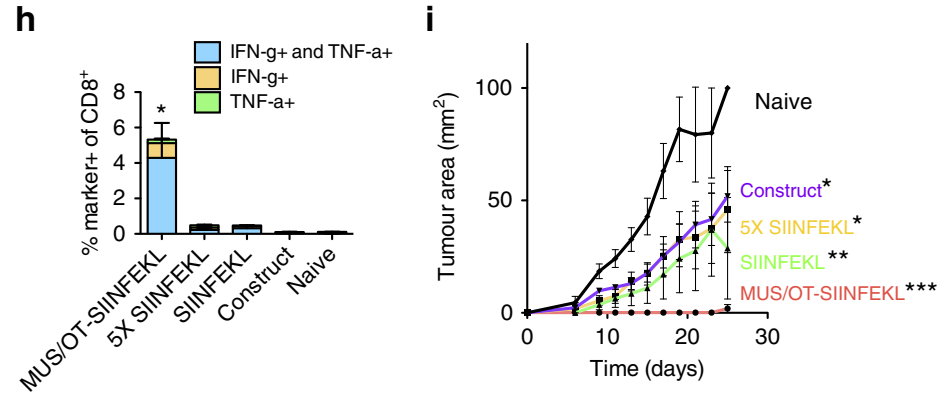

Figure 1 